\title{
Belgeo
}

Revue belge de géographie

4 | 2018

Transformations of urban space after the fall of

Socialism

\section{Constructing urban cultural landscapes \& living in the palimpsests: a case of Moscow city (Russia) distant residential areas}

Ivan Mitin

\section{CpenEdition}

\section{Journals}

Electronic version

URL: http://journals.openedition.org/belgeo/28126

DOI: $10.4000 /$ belgeo.28126

ISSN: 2294-9135

Publisher:

National Committee of Geography of Belgium, Société Royale Belge de Géographie

Electronic reference

Ivan Mitin, « Constructing urban cultural landscapes \& living in the palimpsests: a case of Moscow city (Russia) distant residential areas », Belgeo [Online], 4| 2018, Online since 05 November 2018, connection on 09 October 2020. URL : http://journals.openedition.org/belgeo/28126 ; DOI : https:// doi.org/10.4000/belgeo.28126

This text was automatically generated on 9 October 2020 .

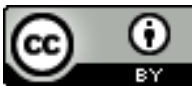

Belgeo est mis à disposition selon les termes de la licence Creative Commons Attribution 4.0 International. 


\title{
Constructing urban cultural landscapes \& living in the palimpsests: a case of Moscow city (Russia) distant residential areas
}

\author{
Ivan Mitin
}

I'm thankful to Uliana Seresova, Assistant Professor of Academy of Public Administration of Moscow region (Russia) for her assistance in the empirical study mentioned in the article.

1 Every city is a place, a place we live in or a place we love, a place we are willing to leave or a place we hate. That means, that any place has multiple functions, visions, representations, emotional ties with people. A model of palimpsest is a one I use hereby to consider that inevitable multiplicity.

2 The structure of this article is as follows. At first I study the history of the "place as palimpsest" concept, trying to single out what it could mean to geographers and social scientists. The contradiction of the idea of symbolic construction of cultural landscapes originating from the new cultural / humanistic geography and the turn to everyday life practices of people shaping the landscape (typical for critical geographies) is in the focus of the $2^{\text {nd }}$ part of this paper. Finally I use an example of a cultural project I've designed in Moscow (Russia) in order to describe how this original place model and these contradictory concepts are shaped and contested in a Post-Socialist city.

\section{Place as palimpsest}

3 The term "palimpsest" originally described a medieval manuscript in which new text was written over previous text that had been erased. The word originates from the Greek "palin"+ "psaio" ("again I scrape"). What was peculiar about palimpsests was the fact that any layer didn't fully erase their predecessors, so one could always recognize the previous layers of the text written earlier (Mitin, 2010). These specific features have made a palimpsest an important metaphor used in social sciences and the humanities 
to stress multiplicity of a text or phenomenon, to witness its layering and to single out some - by chance partly hidden - layers of reality.

The idea of palimpsest was borrowed by geographers from the theories of architecture and urban history. The original metaphor was used to describe the coexistence of material elements that originated in different historical periods in a building or an urban site. This is how A. Baglajewski describes Gdansk city in Poland:

"Textual Gdansk - to say it from the very beginning - is a place-palimpsest of mixed \& hidden civilization and material cultural layers, a specific melting pot of traces, fragments, elements that may be pulled out of the recent new layers and read in different languages [...]. Gdansk is made of those layers taken together, but not any of them alone" (Baglajewski, 1998, pp. 9-11).

5 This seems close to the classic interpretations of temporal changes in the cultural landscapes (Sauer, 1963) and sequent occupance (Whittlesey, 1929). However it was transformed into a certain model within historical geography by J. Vervloet in the 1980s only (Vervloet, 1984).

Figure 1. Historical-geographical model of landscape as palimpsest.

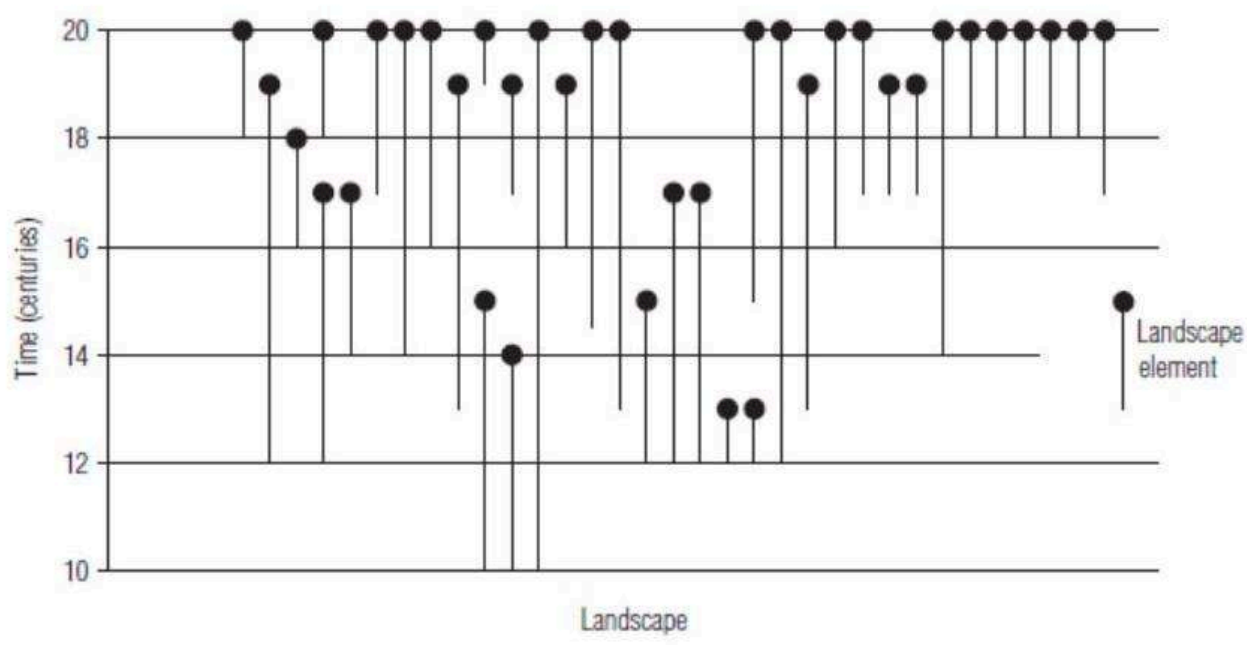

Vervloet, 1984, p. 2; translation: Urbanc et al., 2004, p. 119

6 The first geographer to call a landscape a palimpsest was obviously Donald Meinig (Meinig, 1979) who wrote in the preface to a famous volume "The Interpretation of Ordinary Landscapes" that "it is at once a panorama, a composition, a palimpsest, a microcosm; $[. .$.$] in every prospect there can be more and more that meets the eye"$ (Meinig, 1979, p. 6).

7 The meaning of a landscape as palimpsest was thus changed due to the cultural turn. The palimpsest "provides the possibility for erasure and overwriting and the coexistence of several different scripts, implying not just different historical eras, but several historical and contemporary actors as well" (Schein, 1997, p. 662). What Richard Schein meant here was the very multiplicity of human interpretations and representations of a place. The palimpsest model turns out to be not about the temporal changes alone, but also about the differences in the landscape as it is "read" by social groups and individuals, differentiated by identity, occupation, lifestyles, experience, imaginative power, and emotional factors (Mitin, 2010). 
This turns any cultural landscape - no matter at what time period it originated - into "a sum of erasures, accretions, anomalies and redundancies over time" (Crang, 1998, p. 22). In terms of the "linguistic turn" (Lees, 2002) we are likely to call a landscape a text that can be read (Cosgrove, Jackson, 1987; Duncan, 1990; Lavrenova, 2010; Rowntree, 1986). As Lewis puts it, "reading landscapes is not as easy as reading books" as "ordinary landscape seems messy and disorganized, like a book with pages missing, torn and smudged; a book whose copy has been edited and re-edited by people with illegible handwriting" (Lewis, 1979, p. 12). The landscape is seen as a specific kind of text, in which "different layers or fragments of texts can get into conflict, questioning and contesting each other. Unavoidably inviting controversial interpretation, the reading of such a palimpsest is more like a process of multivocal, and often ambiguous, communication than an act of linear understanding. In modern and postmodern theory of text and communication, this process has been called 'intertextuality"' (Brockmeier, 2001, p. 222).

9 The model of palimpsest turns the "landscape as text" into an intertext, that is a structure of mutual references of multiple meanings (Kristeva, 1969; Barthes, 1973). Thus I define palimpsest as "a conceptual model of a place as a multilayered structure that emphasizes the coexistence of multiple visions and impacts of different cultures on the landscape" (Mitin, 2010, p. 2111).

\section{Urban cultural landscape: symbolic construction vs. lived practices}

10 The model of a multivocal place as a palimpsest has become a result of cultural turn in geography, as I have mentioned above. The development of cultural geography from the classical theories of the beginning of the $\mathrm{XX}^{\text {th }}$ century (Sauer, 1925) to the second half of the $\mathrm{XX}^{\text {th }}$ century was contradictory, yet important. The cultural turn has become a main trend of that change (Gritzner, 1966; Norton, 1981; 1984; Mikesell, 1978; Zelinsky, 1973).

11 The representatives of the new cultural geography criticized the Sauerian Berkeley school for focusing "their studies on the material artifacts, exhibiting a curious and thoroughly antiquarian 'object fetishism' over such items as houses, barns, fences and gasoline stations" (Price, Lewis, 1993, p. 3). Instead, they regard the cultural landscape through its human interpretation, symbolization \& signification (Brace, 2003; Robertson, Richards, 2003; Rowntree, Conkey, 1980). They stated that "the total cultural landscape is information stored in symbolic form" that "in part functions as a narrative" (Rowntree, Conkey, 1980, p. 461), and "the symbolic qualities of landscape, those which produce and sustain social meaning, have become a focus of research" as this "allows us to disclose the meanings that human groups attach to areas and places and to relate those meanings to other aspects and conditions of human existence" (Cosgrove, Jackson, 1987, p. 96).

12 This idea of place as being constructed has been developed in various directions inside humanistic geography (Tuan, 1974, 1976; Hall, 1978; Entrikin, 1985; Hasson, 1984). "Space is transformed into place as it acquires definition and meaning", Yi-Fu Tuan (1977 [2002], p. 136) states. “The central concept is 'meaning', and indeed 'place' may be redefined as coming into existence through men according meaning to locations" 
(Jeans, 1979, pp. 207-208). Dennis Jeans found the exact words for that constructing perspective: "To make a place is to surround a locality with human meanings" (Jeans, 1979, p. 209).

13 My model of a palimpsest originates from the vision of a place as a "fuzzy set" of diverse interpretations, not only historically different elements, as legitimized by new cultural / humanistic geography. To touch upon the relations between various layers of one and the same place, the semiotic model of mythogeography is used (Mitin, 2007).

"Mythogeography's main peculiarity is in the special vision of the 'filling' of every place with constructed realities, created with the help of mythological models of communication and the theory of the semiosis of modern myths" (Mitin, 2007, p. 215). The model combines several theoretical frameworks described below.

First, we need to look on each layer of that "place as palimpsest" alone. Yi-Fu Tuan regarded those layers as place narratives (Tuan, 1991), however I argue they are rather contexts, as each layer of the palimpsest is centered by a few unique dominant peculiarities of a place (Mitin, 2004). This idea is borrowed from the theory of regional geography.

Geographers have been traditionally saying about the process of construction of the texts describing this or that place through the theory of regional geography. Those layers are in fact special kinds of those texts. Different modes of geographical descriptions have been described throughout the XX ${ }^{\text {th }}$ century (Darby, 1962; Davis, 1915; Finch, 1934; Hart, 1982; Lewis, 1985; Paterson, 1974). Being opposed by the positivist view of storing the entire data on any place in a form of encyclopedic classification, the idea of a good description as a geographer's art of constructing a place is as follows.

"Good regional geography should begin with, and probably should be organized around, the dominant theme of each region, which of course will vary from region to region. No standard list of criteria or checklist of features-to-be observed can be universally applicable to the study of all regions [...]. Features that are overwhelmingly important in one region may be completely missing in another, and the regional geographer should give pride of place in each region to its most important or significant features" (Hart, 1982, p. 23).

17 The history of Soviet human geography has been to a larger extent focused on the regions (though primarily economic ones) and regionalization. As a result, the theory of regional geography ("stranovedeniye") has been productively discussed and developed (Baransky, 1950, 1980; Yefremov, 1981; Mashbits, 1998; Mironenko, 1992; Mitin, 2004). Combining the Anglo-American debates on the "highest form of geographer's art" with those Russian concepts, I argue that "genuine complex geographical descriptions should be based on picking the dominant features of place and adopting the secondary features to the dominant with the usage of internal and external textual interconnections" (Mitin, 2007, p. 219).

For example, there is no use in making a full long description of St. Petersburg in Russia if our message is to stress its dominant feature in the sphere of tourism as a "cultural capital of Russia". World famous State Hermitage, Peterhof and other museums, the historical intent of Peter the Great as the city founder to build a new capital "sticking" Russia to Europe, and the largely discussed special intellectual and authentic local identity would be those secondary features revealing and explaining the dominant one.

While that legitimizes certain rules of constructing each layer of place as palimpsest as a context, I need other theoretical frameworks to describe how the combination of 
various layers is created. The layers seem autonomous, and their hierarchy is easily changeable under the internal and external circumstances. However, the psychological essence of perception \& imagination processes makes us always consider one of those layers the main - the dominant - one, though we may change our mind immediately. The palimpsest is a unite totality of those autonomous layers, that regards a place as multidimensional.

To understand how that totality is created through representations the semiotic model of semiosis is used to describe the interconnections between the autonomous layers of the palimpsest. A theory of modern mythologies as developed by Roland Barthes (1972 [1991]) turned out to be the best framework with each layer regarded as a certain spatial myth. Similarly to the place within humanistic geography, "mythical speech is made of a material which has already been worked on so as to make it suitable for communication" (Barthes, 1972 [1991], p. 108).

"In myth, we find again the tri-dimensional pattern [...]: the signifier, the signified and the sign. But myth is a peculiar system, in that it is constructed from a semiological chain which existed before it: it is a second-order semiological system. That which is a sign (namely the associative total of a concept and an image) in the first system, becomes a mere signifier in the second. We must here recall that the materials of mythical speech (the language itself, photography, painting, posters, rituals, objects, etc.), however different at the start, are reduced to a pure signifying function as soon as they are caught by myth. Myth sees in them only the same raw material; their unity is that they all come down to the status of a mere language" (Barthes, 1972 [1991], p. 113).

Figure 2. Myth as a semiological system.

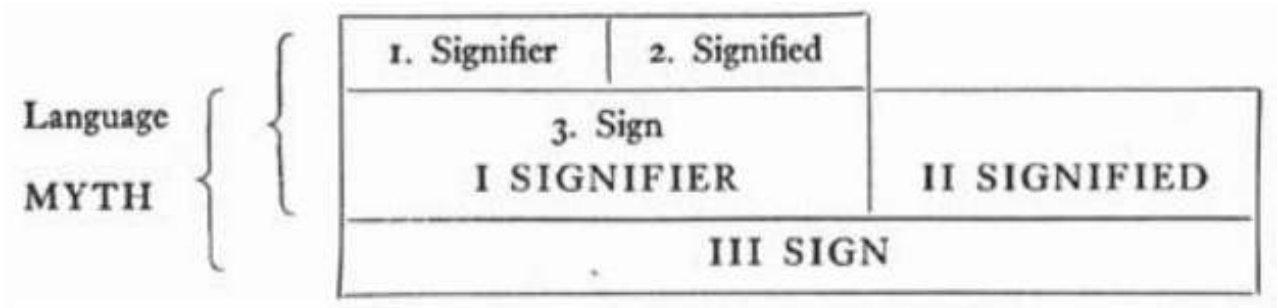

Barthes, 1972 [1991], p. 113

The vision of urban imageries through myths' semiosis explains how multiple representations are constructed through history, and the new ones replace the previous ones. For example the myth of St. Petersburg as the "bandits' capital of Russia" emerging in the 1990s was to a much extent based on its strong opposition to the previously stated idea of country's cultural capital.

The process of semiosis (Figure 2) is usable for the endless number of re-interpretations of spatial meanings, as the essence of any certain place (or any previously constructed place image) is reduced to a form of a myth that constructs a new meaning out of one and the same place (Mitin, 2004).

Combining (a) the idea of the cultural landscape as being constructed through symbolic values, (b) the theory of regional geographical descriptions, and (c) the semiotic model of modern mythologies altogether form a model of place as palimpsest as being created and re-created. However, it is to a much extent settled within a representational paradigm of geography. 

concern about certain rematerializing of the discipline, or a call towards combining material and immaterial realms as typical for contemporary urban geography (Lees, 2002). "real" in that thirdspace, Lefebvre moves forward describing what kind of space it is. "Every society [...] produces a space, its own space" (Lefebvre, 1991, p. 31), and the society we live in is named as completely urbanized, or simply "the urban society" (Lefebvre, 2003). While the previous mode of a city linked to the industrial society is seen as rationally planned and characterized by imposed homogeneity, the urban society and its space make a certain opposition to it.

"During this new period differences are known and recognized, mastered, conceived and signified. [...] It is constituted by a renewed space-time, a topology that is distinct from agrarian (cyclic and juxtaposing local particularities) and industrial (tending towards homogeneity, toward a rational and planned unity of constraints) space-time. Urban space-time, as soon as we stop defining it in terms of industrial rationality - its project of homogenization - appears as a differential, each place and each moment existing only within a whole, through the contrasts and oppositions that connect it to, and distinguish it from, other places and moments [...]. The urban space is complete contradiction" (Lefebvre, 1991, pp. 37-39).

The urban space is stressed to be complex, heterogeneous, multifaceted, interrelated. This vision of the new space constitution revives the idea of a palimpsest, as the latest embraces that very endless multiplicity co-existing in one and the same place. What is needed, is to shift the focus from those layers being constructed to the places being lived and experienced.

\section{Mobile quest games in Moscow distant residential areas}

In order to implement the model of "place as palimpsest" in practice in the sphere of urban cultural policy and to create that mix of representational and lived modes of a cultural landscape I elaborated a project of mobile quest games. It is aimed at the cultural 
development of distant residential areas of Moscow (Russia) city which lack both unique local imageries and place-specific practices. The process of creation of the images which stick to those placeless distant areas (as a part of project management) is regarded through the lens of symbolic construction of urban cultural landscapes. The process of local dwellers using the quest games and getting acquainted with the suggested unique features of their own home areas is regarded as lived consumption of places and changing the lived practices.

The project including the launch of 22 mobile quest games during 2015-2017 was implemented by "Moscow Agency for Area Development through Culture" ("MosART") as the operator. The Agency was founded by the Department of Culture of the Moscow city Government as a cultural events' management and methods' development centre for promoting socio-cultural activity outside the centre of the city, in particular, outside the Third Ring Road. "MosART" has been an official name of the Agency till 2016, when it was renamed into "Cultural Centre 'Ivanovsky" without changes in its main functions.

Mobile quest games were suggested as an alternative to traditional excursions, as the areas outside of the city centre have been traditionally out of tourist interest and were not regarded as important leisure sights by local residents. There are a few sights outside the Third Ring Road, which are considered to be tourist objects, like Tsaritsyno or Kolomenskoye museums and parks. Those popular places were intentionally excluded from the project.

Traditional excursions are hardly possible in the areas with poor tourist infrastructure, the attractions in physically poor condition, located far one from another, and/or representing industrial / engineering heritage, or traditional residential blocks from the $\mathrm{XX}^{\text {th }}$ century, that are rarely considered valuable as tourist destinations in contemporary Russia. Those objects and areas were intentionally chosen for the project.

33 Muscovites are considered the main target audience of the project according to the Department of Culture's policy agenda.

New cultural / humanistic geography, the ideas of symbolic construction of tourist sights and the model of "place as palimpsest" were considered to be the theoretical background of the project. It was thought to be a means of creating new attractive sights in distant residential areas and constructing the new local images which could become important parts of local imageries, areas' branding and promoting local identities.

All mobile quest games are promoted at the Agency's website (https://ivcenter.ru/ project/vse-kvesti/) and through Moscow city official cultural and tourist websites and social media. As soon as a user chooses one of the quest games from the website, s/he is forwarded to a web page of "Street Adventure" company, a project partner responsible for technical support. In a few minutes after being registered at that web page the user receives the individual link to start the quest game online. Users follow the directions from that link, receive the questions and insert their answers online using their tablets or smartphones, and thus follow the route of the quest game. Apart from providing questions and checking the answers, the online interface provides the attractive information about the places visited, that might be useful to answer the questions, but is more likely to serve to create the certain images of the places and the area as a whole. 
An example of that kind of a small text about "Fabrika 1 Maya" settlement, located in the Novomoskovsky district of Moscow in some $30 \mathrm{~km}$ from the Kremlin, that became a part of the city in 2012 only, is below.

A cloth factory opposite has an interesting history. It was first mentioned in 1853 as a possession of D.A. Okulova. She married Nikolay Pavlovich Shipov, a colonel and a real state councilor famous for the agricultural innovations he implemented in his Ostashevo estate near Mozhaysk, Moscow region. Okulova was also acquainted to Pyotr Vyazemsky, a poet and an owner of the neighboring Ostafyevo estate that we have just visited. The factory was sold to engineer Ivan Ivanovich Baskakov in 1879, however there is an evidence that Baskakov reconstructed the estate and built a new factory. He also built a dam across the Desna river, though the one you'll see as you walk a hundred meters upstream has been seriously rebuilt later on. Baskakov also constructed the manufacturer's estate and the red-brick barracks for the workers. Some of them are still used as residential houses. Those were probably built before 1912, though we can't know that for sure. However, there is a building further on with a construction year you can know for sure. Find it and insert that year as an answer!

Tip 1: Walk between the houses on the Desna river bank.

Tip 2: Find a house No. 3.

Answer: 1927.

The tips from the example are used if the user fails to find the right answer or loses the way.

Some 22 mobile quest games were launched for three years, and $34000+$ people played at least one of them. The exact user statistical data is below (Table 1).

Table 1. User statistics for mobile quest games by “MosART", by December 31, 2017.

\begin{tabular}{|c|c|c|c|}
\hline No. & Mobile quest game name (District of Moscow) & $\begin{array}{l}\text { Launch month / } \\
\text { year }\end{array}$ & Users \\
\hline 1 & $\begin{array}{l}\text { "Here stands, with shady park surrounded, Petrovsky Castle..." } \\
\text { (Northern) }\end{array}$ & April 2015 & 2996 \\
\hline 2 & $\begin{array}{l}\text { From Pasternak to "The Tale of Igor's Campaign" } \\
\text { (Novomoskovsky) }\end{array}$ & April 2015 & 2224 \\
\hline 3 & Military history patriotic automobile quest (Troitsky) & May 2015 & 2096 \\
\hline 4 & Detective (Troitsky and Novomoskovsky) & May 2015 & 2488 \\
\hline 5 & Moscow milestones (Zelenogradsky) & May 2015 & 2184 \\
\hline 6 & Cottages, barracks \& a factory on Yauza river (Eastern) & May 2015 & 3404 \\
\hline 7 & Hidden Pererva (Southeastern) & June 2015 & 2812 \\
\hline 8 & Different Vorobyovy hills (Western) & August 2015 & 4548 \\
\hline 9 & Unknown Biryulevo (Southern) & August 2015 & 1996 \\
\hline 10 & $\begin{array}{l}\text { Pokrovskoye-Streshnevo springs, beavers and river locks } \\
\text { (Northwestern) }\end{array}$ & August 2015 & 2660 \\
\hline
\end{tabular}




\begin{tabular}{|l|l|l|l|}
\hline 11 & Follow the traces of ancient estates (Southwestern) & September 2015 & 1976 \\
\hline 12 & To the Yauza river banks (Northeastern) & September 2015 & 1900 \\
\hline 13 & Around "Mosfilm" film studio (Western) & March 2016 & 708 \\
\hline 14 & Read Sviblovo (Northeastern) & April 2016 & 340 \\
\hline 15 & To the birthplace of "Moscow Nights" song (Troitsky) & June 2016 & 144 \\
\hline 16 & "Could One Imagine?" (entire city) & August 2016 & 280 \\
\hline 17 & Rostokino, the "most cinematic" area (Northeastern) & September 2016 & 1308 \\
\hline 18 & Follow the old "Vladimirka" road to the Saint lake (Eastern) & March 2017 & 236 \\
\hline 19 & $\begin{array}{l}\text { By "literary streets" to the Solomennaya Storozhka } \\
\text { (Northeastern, Northern) }\end{array}$ & April 2017 & 64 \\
\hline 20 & New Moscow, the open-air museum (Novomoskovsky) & May 2017 & 32 \\
\hline 21 & Forest paths of Belokamennaya (Eastern, Northeastern) & June 2017 & 148 \\
\hline 22 & Dragons of the Serebryany Bor (Northern, Northwestern) & September 2017 & 12 \\
\hline
\end{tabular}

The analysis shows, that in spite of the effort to promote the most distant and unknown areas of the city, the most closely connected to the Third Ring Road and the most wellknown areas were the most popular. Vorobyovy hills seem the best evidence here: though the route passes through the historic picturesque park, the viewpoint on top of Vorobyovy hills is a known tourist sight, and its name attracts the users to this mobile quest game (No. 8 in Table 1). However, I argue that by means of the project even the least attended areas could be transformed from real "non-places" into certain meaningful places, though not widely known and recognized.

\section{Lived practices of the quest game users}

The idea of the project of mobile quest games was in fact to create a new layer of place as palimpsest. The possible influence of those new representations towards lived practices of people is critically important in the light of critical non-representational urban geography. An experiment was held in order to study those effects of mobile quest games towards everyday lived practices of its users. I needed to check if there was any influence of playing the quest game on (a) the imagery of the area, and (b) the estimations of its comfort for everyday living. 60 students of the Academy of Public Administration of Moscow region were asked to pass 2 quest games in the Northeastern district of Moscow, not far from their campus and dormitories, and share their statements and images of Sviblovo area before and after the experiment. Sentence completion and drawing tests were used as an initial point of the research to learn about the current imageries of Sviblovo area. The survey was held for the participants of one of 2 routes $(\mathrm{N}=32)$ to check if the imagery was changed. Observation and in-depth interviews 
$(\mathrm{N}=12)$ were used to witness the essence of the new local images and the new lived practices possibly emerging after the completion of the game.

The initial image of the area (Figure 3) included the underground (metro) station and the Academy campus for the majority of informants. Those living in the dormitories also mentioned the shopping malls and the restaurants in the vicinity (an example is in the left part of the Figure 3). A small "Zodiac park" established in 2007 was mentioned a few times, as well as the Kapustinsky pond. Nothing more than some points of the students' everyday routine was pictured.

Figure 3. A typical drawing of Sviblovo area.

Image 1000000000000FD80000088780AA1746.png

Female, from Moscow region, living in the dormitory

Some of the students used Wikipedia data in the sentence completion test to mention the exact amount of inhabitants of the area, the Yauza river and the fact that the famous Soviet comedy "Operation Y and Shurik's Other Adventures" was filmed there. Sviblovo was generally characterized in the sentence completion tests as a distant dull area of residential blocks with no specific sights to visit.

The final image was influenced by the mobile quest game. $66 \%$ of quest users agreed that their image of the area was changed after the game according to the survey conducted, and $75 \%$ of the latter said it has become more positive. The interviews could help me to understand the substantial changes. The users mentioned the old estate, the houses filmed in the Soviet comedy movie, some streetart objects, which were a surprise for them in their neighborhood:

"We didn't feel anything special at first. It was all ours, so familiar. But it was astonishing to see that street-art object, as I've never noticed it before" (Female, from Central Asia, living in the dormitory).

"I would say, I have opened Sviblovo from so different sides after all, though a heavy rain started. It was [previously] just a place where I study, and that's all of it" (Female, from Moscow, living in another district of Moscow). However, the idea of Sviblovo as a historic neighborhood that could be "read" through literary sources and famous movies was not transferred to the quest users.

The picturesque Yauza river bank was one of the most discussed places together with a neighboring old estate. There was even an idea for new everyday practices mentioned in one of the interviews:

"It would be not bad to go for a walk on those grounds near the [Yauza] river, may be in summertime with my boyfriend. It creates a special atmosphere, [it is] helpful to forget about the routine" (Female, from another region, living in the dormitory).

However this was the only mention of any possible changes in the lived uses of a place. The transformation of the local imagery, which I would regard as the influence of a new representation constructed, was hardly influential enough to give birth to the new practices which remained unchanged. 


\section{Conclusion} geographical research and cultural management with broader horizons of place management seem necessary and prospective. 


\section{BIBLIOGRAPHY}

BAGLAJEWSKI A. (1998), “Misto. Palimpsest” (“Place. Palimpsest”), Ji Magazine, 13, pp. 109-131, http://www.ji.lviv.ua/n13texts/baglajews.htm.

BARANSKY N.N. (1950), "Bol'she zaboty ob iskusstve geograficheskogo opisanija” ("More care about the art of geographical description"), Voprosy Geografii, 18, Moscow, OGIZ, pp. 90-101.

BARANSKY N.N. (1980), "O svjazi yavlenij v ekonomicheskoj geografii” ("On the connection of phenomena in economic geography”), in BARANSKY N.N., Izbrannyje trudy: Stanovlenije sovetskoj ekonomicheskoj geografii ("Selected writings: The establishment of Soviet economic geography"), Moscow, Mysl', pp. 160-172.

BARTHES R. (1972 [1991]), Mythologies, $25^{\text {th }}$ printing, New York, The Noonday Press.

BARTHES R. (1973), “Texte”, Encyclopaedia universalis, Paris, Encyclopaedia universalis, 15, p. 78.

BRACE C. (2003), “Landscape and identity”, in ROBERTSON I., RICHARDS P. (eds.), Studying Cultural Landscapes, London, Arnold Publishers, pp. 121-140.

BROCKMEIER J. (2001), "Texts and other symbolic spaces", Mind, culture and activity, 8, 3, pp. 215-230.

COSGROVE D., JACKSON P. (1987), “New directions in cultural geography”, Area, 19, 2, pp. 95-101. CRANG M. (1998), Cultural geographies, London, Routledge.

DARBY H.C. (1962), "The problem of geographical description”, Transactions of the Institute of British Geographers, 30, pp. 1-14.

DAVIS W.M. (1915), "The principles of geographical description”, Annals of the Association of American Geographers, 5, pp. 61-105.

DUNCAN J.S. (1990), City as Text: Politics of Landscape Interpretation in the Kandyan Kingdom, Cambridge, Cambridge University Press.

ENTRIKIN J.N. (1985), “Humanism, naturalism and geographical thought”, Geographical Analysis, 17,3 , pp. 243-247.

FINCH V.C. (1934), "Written structures for presenting the geography of regions", Annals of the Association of American Geographers, 24, 2, pp. 113-122.

GENTILE M. (2018), “Three metals and the 'post-socialist city': Reclaiming the peripheries of urban knowledge”, International Journal of Urban and Regional Research, 42 (Early View, DOI: 10.1111/1468-2427.12552), pp. 1-12.

GRITZNER C.F. (1966), “The scope of cultural geography”, Journal of Geography, 65, 1, pp. 4-11.

HALL R. (1978), “Teaching humanistic geography”, Australian Geographer, 14, 1, pp. 7-14.

HART J.F. (1982), “The highest form of the geographer's art", Annals of the Association of American Geographers, 72, 1, pp. 1-29.

HASSON S. (1984), "Humanistic geography from the perspective of Martin Buber's philosophy", Professional Geographer, 36, 1, pp. 11-18.

JEANS D.N. (1979), "Some literary examples of humanistic descriptions of place", Australian Geographer, 14, 4, pp. 207-214. 
KRISTEVA J. (1969), Semiotike: Recherches pour une semanalyse, Paris, Seuil.

LAVRENOVA O.A. (2010), Prostranstva i smysly: Semantika kul'turnogo landshafta ("Spaces \& senses: Semantics of cultural landscape"), Moscow, Heritage Institute.

LEES L. (2002), “Rematerializing geography: The 'new' urban geography”, Progress in Human Geography, 26, pp. 101-112.

LEFEBVRE H. (1991), The Production of Space, Oxford, Basil Blackwell.

LEFEBVRE H. (2003), The Urban Revolution, Minneapolis, London, University of Minnesota Press.

LEWIS P.F. (1979), "Axioms for reading the landscape. Some guides to the American scene", in MEINIG D.W. (ed.), The Interpretation of Ordinary Landscapes: Geographical Essays, New York, Oxford, Oxford University Press, pp. 11-32.

LEWIS P. (1985), "Beyond description”, Annals of the Association of American Geographers, 75, 4, pp. 405-477.

MASHBITS Ya.G. (1998), Kompleksnoje stranovedenije (“Complex regional geography”), Smolensk, SGU.

MCMANUS P. (2004), "Writing the palimpsest, again; Rozelle Bay and the Sydney 2000 Olympic games", Urban policy and research, 22, 2, pp. 157-167.

MEINIG D.W. (1979), “Introduction”, in MEINIG D.W. (ed.), The Interpretation of Ordinary Landscapes: Geographical Essays, New York, Oxford, Oxford University Press, pp. 1-7.

MIKESELL M.W. (1978), "Tradition and innovation in cultural geography”, Annals of the Association of American Geographers, 68, 1, pp. 1-16.

MIRONENKO N.S. (1992), "Kontseptsii sinteza v sovremennom stranovedenii” ("The synthesis concepts in modern regional geography"), Vestnik Moskovskogo Universiteta, Series Geography, 1, pp. 3-7.

MITIN I. (2004), Kompleksnye geograficheskie kharakteristiki. Mnozhestvennye real'nosti mest $i$ semiozis prostranstvennyh mifov ("Complex Geographical Descriptions. Multiple Realities of a Place and Spatial Myths' Semiosis”), Smolensk, Oecumene.

MITIN I. (2007), "Mythogeography - region as a palimpsest of identities", in ELENIUS L., KARLSSON C. (eds.), Cross-Cultural Communication and Ethnic Identities, Luleå, Luleå University of Technology, pp. 215-225.

MITIN I. (2010), "Palimpsest”, in WARF B. (ed.), SAGE Encyclopedia of Geography, Thousand Oaks, CA, London, New Delhi, Singapore, SAGE, 4, pp. 2111-2112.

NORTON W. (1981), “Cultural analysis in geography: A course outline”, Journal of geography, 80, 1, pp. 46-51.

NORTON W. (1984), “The meaning of culture in cultural geography: An appraisal”, Journal of geography, 83, 4, pp. 145-148.

PATERSON J.H. (1974), “Writing regional geography: problems and progress in the AngloAmerican realm”, Progress in Geography, 6, pp. 1-26.

PRICE M., LEWIS M. (1993), “The reinvention of cultural geography”, Annals of the Association of American Geographers, 83, 1, pp. 1-17.

ROBERTSON I., RICHARDS P. (2003), "Introduction” in ROBERTSON I., RICHARDS P. (eds.), Studying Cultural Landscapes, London, Arnold Publishers, pp. 1-18. 
ROWNTREE L.B. (1986), “Cultural/humanistic geography”, Progress in Human Geography, 10, pp. 580-586.

ROWNTREE L.B., CONKEY M.W. (1980), "Symbolism and cultural landscape”, Annals of the Association of American Geographers, 70, 4, pp. 459-474.

SAUER C.O. (1925), “The morphology of landscape”, Publications in Geography, Berkeley, University of California, 2, 2, pp. 19-53.

SAUER C.O. (1963), Land and Life, Berkeley, CA, Los Angeles, University of California Press.

SCHEIN R.H. (1997), "The place of landscape: A conceptual framework for interpreting an American scene", Annals of the Association of American Geographers, 87, 4, pp. 660-680.

SOJA E.W. (1996), Thirdspace: Journeys to Los Angeles and Other Real-and-Imagined Places, Oxford, Basil Blackwell.

TUAN Y.-F. (1974), Topophilia: A study of environmental perception, attitudes and values, Englewood Cliffs, N.J., Prentice-Hall, Inc.

TUAN Y.-F. (1976), “Humanistic geography”, Annals of the Association of American Geographers, 66, 2, pp. 266-276.

TUAN Y.-F. (1977 [2002]), Space and Place. The Perspective of Experience, $9^{\text {th }}$ ed., Minneapolis, London, University of Minnesota Press.

TUAN Y.-F. (1991), “Language and the making of place: A narrative-descriptive approach”, Annals of the Association of American Geographers, 81, 4, pp. 684-696.

URBANC M., PRINTSMANN A., PALANG H., SKOWRONEK E., WOLOSZYN W. \& GYURÓ E.K. (2004), "Comprehension of rapidly transforming landscapes of Central and Eastern Europe in the $20^{\text {th }}$ century", Acta geographica Slovenica, 44, 2, pp. 101-131.

VERVLOET J.A.J. (1984), Inleiding tot de historische geografie van de Nederlandse cultuurlandschappen, Wageningen, Pudoc.

WHITTLESEY D. (1929), "Sequent Occupance”, Annals of the Association of American Geographers, 19, 3, pp. 162-165.

YEFREMOV Yu.K. (1981), “O logike i metodike stranovedcheskikh kharakteristik (v svete idej N.N. Baranskogo)" ("On the logic \& methods of regional geographical descriptions (in the light of N.N. Baransky's ideas)”), Voprosy Geografii, 116, Moscow, Mysl', pp. 28-35.

ZELINSKY W. (1973), The Cultural Geography of the United States, Englewood Cliffs, N.J., PrenticeHall, Inc.

\section{ABSTRACTS}

A metaphor of palimpsest is used to describe the multivocal cultural landscapes since the 1970s. Interventions into new cultural / humanistic geography, semiotics and the theory of regional geography help to regard each layer of the palimpsest as a constructed context, centered by dominant representation of a place.

Real-and-imagined landscapes are regarded as palimpsests lived through everyday practices seen as processes of (re)construction of new layers.

Trying to unite those "constructing' and "living' perspectives is a challenging task for urban cultural agenda.

A series of mobile quest games was made by the author for Moscow Agency for Area 
Development through Culture in order to construct new tourist sights outside city centre. This project is discussed as a case of constructing new geographical contexts (palimpsest' layers) and the lived experience rediscovering the distant residential areas, traditionally regarded as standardized "non-places', as becoming rich in symbolic capital.

La métaphore du palimpseste est utilisée pour décrire les paysages culturels polysémiques depuis les années 1970. Les emprunts à la nouvelle géographie culturelle/humaniste, à la sémiotique et à la théorie de la géographie régionale aident à percevoir chaque couche du palimpseste comme un construit contextualisé, centré sur une représentation dominante d'un lieu.

Les paysages à la fois réels et imaginés sont envisagés comme des palimpsestes vécus à travers des pratiques quotidiennes, elles-mêmes vues comme des processus de (re)construction de nouvelles couches.

Tenter d'unifier ces perspectives en construction et vécues est un enjeu à l'agenda de la culture urbaine.

Une série de jeux de questions sur le terrain ont été construits par l'auteur pour l'Agence moscovite du développement par la culture, afin de construire de nouvelles perspectives touristiques en dehors du centre de Moscou. Ce projet est discuté comme étude de cas d'une volonté de construction de nouveaux contextes géographiques (couches du palimpseste) et d'une expérience vécue de redécouverte de zones résidentielles périphériques, traditionnellement perçues comme des "non-lieux" standardisés, mais qui pourraient acquérir un riche capital symbolique.

\section{INDEX}

Keywords: urban geography, palimpsest, cultural landscape, cultural policy, Russia, Moscow Mots-clés: géographie urbaine, palimpseste, paysage culturel, politique culturelle, Russie, Moscou

\section{AUTHOR}

\section{IVAN MITIN}

National Research University Higher School of Economics (Moscow), imitin@hse.ru 